\title{
HUBUNGAN KADAR KOMPONEN BESI DARAH PENDONOR TERHADAP KUALITAS PACKED RED CELLS (PRC) DI UDD PMI PROVINSI SUMATERA SELATAN
}

\author{
Relationship Between Iron Component Level of Donors and Packed Red Cells (PRC) \\ Quality in UDD PMI Provinsi Sumatera Selatan
}

\author{
Rahmi Widiwawati I* \\ Zen Hafy 2 \\ Phey Liana ${ }^{3}$ \\ IProgram Studi Magister IImu \\ Biomedik Fakultas Kedokteran, \\ Universitas Sriwijaya \\ Jalan Raya Palembang- \\ Prabumulih Km. 32 Inderalaya, \\ Ogan Ilir, Sumatera Selatan, \\ 30662 \\ 2,3Bagian Imun dan Sains \\ Transfusi, Fakultas Kedokteran, \\ Universitas Sriwijaya Palembang \\ Jalan Raya Palembang- \\ Prabumulih Km. 32 Inderalaya, \\ Ogan Ilir, Sumatera Selatan, \\ 30662
}

*email: zhafy@yahoo.com

Kata Kunci:

kadar komponen besi

darah pendonor

kualitas PRC

\section{Keywords:}

iron component level

Blood donors

the quality of PRC

\begin{abstract}
Abstrak
Zat besi merupakan salah satu komponen esensial dalam tubuh, terutama dipakai dalam membentuk hemoglobin. Bila zat besi yang masuk dalam tubuh melalui makanan sehari-hari lebih sedikit daripada yang dikeluarkan, maka cadangan besi tubuh akan dimobilisasi serta dipakai sehingga suatu saat dapat timbul defisiensi besi. Tahap pertama dan kedua defisiensi besi ditandai dengan berkurangnya cadangan besi di dalam darah yang sering belum terdeteksi oleh parameter kualitas darah lainnya seperti Hemoglobin dan Hematokrit sehingga masih memungkinkan seseorang pada tahap ini untuk mendonorkan darahnya.

Penelitian ini merupakan studi observasional analitik dengan desain pengambilan data potong lintang. Sebanyak 86 sampel masing-masing berupa Whole Blood pendonor dalam tabung EDTA dan darah dari selang komponen PRC yang dihasilkan dari pendonor yang sama di UDD PMI Sumatera Selatan. Pada sampel darah pendonor dilakukan pemeriksaan kadar $\mathrm{Hb}, \mathrm{Ht}$, Indeks Eritrosit (MCV,MCH,MCHC), Ret-He RDW-CV, Feritin, Serum Iron, TIBC dan Saturasi Transferin. Sedangkan darah dari selang komponen PRC dlakukan pemeriksaan kadar $\mathrm{Hb}, \mathrm{Ht}$ dan Morfologi Eritrosit untuk melihat kualitas PRC.

Hasil penelitian menunjukan bahwa dari 86 sampel yang diteliti, terdapat 7I sampel dengan kadar zat besi yang normal, 9 sampel termasuk kategori defisiensi besi tahap I dan sebanyak 6 sampel termasuk kategori defisiensi besi tahap 2. Semua sampel dengan kategori normal dan defisiensi besi tahap I memiliki kualitas PRC yang baik sedangkan keenam sampel dengan kategori defisiensi besi tahap 2 memiliki kualitas PRC yang rendah.

Kesimpulan, terdapat hubungan antara kadar komponen besi darah pendonor dengan kualitas PRC yang dihasilkan. Penelitian ini menunjukkan bahwa semua darah pendonor dengan keadaan defisiensi besi tahap 2 mempunyai kualitas PRC yang rendah.
\end{abstract}

\footnotetext{
Abstract

Iron is one of the essential components in our body, mainly used to formed Hemoglobin. When the iron enters through daily food is less than issued, the reserves of iron in the body will be mobilized and used, so at some time can caused iron deficiency. The first and second stages of iron deficiency are characterized by reduced iron reserves in the blood, that are often not detected by other blood quality parameters such as Hemoglobin and Hematocrit so that it still allows a person at this stage to donate his blood.

This research is an analytical observational study with cross sectional design. 86 samples each in the form of Whole Blood donors in EDTA and blood from hoses of PRC components produced from the same donors in UDD PMI South Sumatra. In the donor's blood sample, hb, ht, erythrocyte index (MCV, $\mathrm{MCH}, \mathrm{MCHC})$, Ret$\mathrm{He}, \mathrm{RDW}-\mathrm{CV}$, Ferritin, Serum Iron, TIBC and Saturation Transferin were examined. While the blood from the hose component PRC conducted examination of hb levels, $\mathrm{Ht}$ and Erythrocyte Morphology to see the quality of PRC.

The results showed that 86 samples studied, there were 7 I samples with normal iron levels, 9 samples were iron deficiency stage I and 6 samples belonged to the category of iron deficiency stage 2 . All samples with normal category and stage I iron deficiency have good PRC quality while all six samples with stage 2 iron deficiency category have low PRC quality.

In conclusion, there is a relationship between iron component level in blood donors and quality of PRC produced. This research shows that all blood donors with iron deficiency stage 2 have low PRC quality.
} 


\section{PENDAHULUAN}

Anemia merupakan salah satu masalah kesehatan di seluruh dunia terutama negara berkembang. Saat ini diperkirahan $30 \%$ penduduk dunia menderita anemia. Anemia bisa disebabkan oleh defisiensi zat gizi, infeksi akut dan kronis, juga kelainan hemolitik. Anemia yang disebabkan oleh defisiensi zat gizi salah satunya anemia defisiensi besi. Defisiensi besi merupakan masalah umum dan luas dalam bidang gangguan gizi di dunia. Prevalensi anemia defisiensi besi masih tergolong tinggi, sekitar $50 \%$ lebih dari kasus anemia yang ada (WHO, 20II).

Zat besi merupakan salah satu komponen esensial dalam tubuh, terutama dipakai dalam membentuk hemoglobin. Bila besi yang masuk dalam tubuh melalui makanan sehari-hari lebih sedikit daripada yang dikeluarkan, maka cadangan besi tubuh akan dimobilisasi serta dipakai sehingga suatu saat dapat timbul defisiensi besi (Lynch, 2007).

Terdapat tiga tahapan patogenesis defisiensi besi. Tahap pertama disebut iron depletion atau store iron deficiency, ditandai dengan berkurangnya cadangan besi atau tidak adanya cadangan besi, feritin serum menurun sedangkan pemeriksaan lain untuk mengetahui adanya kekurangan besi (Serum Iron, TIBC, Hb, Saturasi Transferin) masih normal. Pemeriksaan kadar feritin serum sudah rutin dikerjakan untuk menentukan diagnosis defisiensi besi, karena terbukti bahwa kadar feritin serum sebagai indikator paling dini pada keadaan bila cadangan besi menurun (Daru, 2017). Menurut World Health Organization (WHO), kadar feritin serum untuk laki-laki I5-200 $\mu \mathrm{g} / \mathrm{L}$ dan untuk perempuan 15-150 $\mu g / \mathrm{L}$ (WHO, 20II). Tahapan kedua yaitu iron deficient erythropoietin atau iron limited erythropoiesis didapatkan suplai besi yang tidak cukup untuk menunjang eritropoesis. Dari hasil pemeriksaan laboratorium diperoleh nilai besi serum menurun dan saturasi transferin menurun, sedangkan Total iron Binding Capacity (TIBC) meningkat $>380 \mu \mathrm{g} / \mathrm{dL}$ dan free erythrocyteporphrin (FEP) meningkat. Pada gambaran darah tepi juga sudah ditemukan sel dengan ukuran mikrosit dan hipokrom serta retikulositosis (Raveendran, 2019). Tahap ketiga, disebut sebagai iron deficiency anemia. Keadaan ini terjadi bila besi yang menuju eritroid sumsum tulang tidak cukup sehingga menyebabkan penurunan kadar Hemoglobin $(\mathrm{Hb})$. Nilai saturasi transferin $<10 \%$, besi serum $<30 \mathrm{mg} / \mathrm{dL}$. Dari gambaran tepi darah didapatkan mikrositosis dan hipokromik yang progesif. Pada tahap ini telah terjadi perubahan epitel terutama pada defisiensi besi yang lebih lanjut serta beberapa enzim yang dapat menimbulkan gejala pada kuku, epitel mulut dan faring serta berbagai gejala lainnya sebagai manifestasi klinis.

Kehilangan besi dalam tubuh sekitar 200-250 mg terjadi saat dilakukan pendonoran darah, untuk setiap 350-450 mL darah yang diambil (Brittenham, 20l I).

Persyaratan pendonor di berbagai negara telah ditetapkan beberapa kriteria seleksi donor yang berfungsi melindungi baik donor maupun resipien, antara lain kadar Hemoglobin $(\mathrm{Hb})$ minimal pada pria $13 \mathrm{~g} / \mathrm{dL}$ dan wanita $12 \mathrm{~g} / \mathrm{dL}$. American Association of Blood Bank (AABB) menetapkan kadar $\mathrm{Hb}$ minimal pada pria $13,5 \mathrm{~g} / \mathrm{dL}$ dan wanita $12,5 \mathrm{~g} / \mathrm{dL}$, sedangkan di Indonesia menurut Pedoman Pelayanan Transfusi Darah dari Unit Donor Darah Pusat Palang Merah Indonesia, kadar $\mathrm{Hb}$ pria dan wanita minimal $12,5 \mathrm{~g} / \mathrm{dL}$ namun pemeriksaan kadar komponen besi tidak dilakukan sebagai pemeriksaan awal terhadap anemia defisiensi besi untuk calon pendonor (PMK no 91, 2015).

Pada pendonor yang memiliki gejala anemia defisiensi besi tahap I dan 2, belum terdeteksi adanya penurunan kadar $\mathrm{Hb}$ yang signifikan sehingga hal ini masih memungkinkan bagi pendonor untuk melakukan transfusi darah. Namun pada pemeriksaan morfologi eritrosit anemia defisiensi besi tahap 2 telah ditemukan kelainan sel eritrosit berupa sel mikrositik hipokrom juga retikulositosis (Raveendran, 2019).

Komponen darah yang paling sering digunakan dalam transfusi darah yaitu Packed Red Cells (PRC) (PPSDM, 20I8). Kualitas komponen PRC selain dilakukan pemeriksaan golongan darah dan IMLTD, kualitas kontrol juga dilakukan dengan pemeriksaan kadar hemoglobin dan hematokrit pada produk komponen darah yang dihasilkan. Tiap unit sekitar 150-200 mL sel darah merah dengan plasma yang sudah dipisahkan memiliki kadar hemoglobin tiap unit sekitar $45 \mathrm{gr}$ dan kadar hematokrit 55-75\% tiap unit (PMK no 91, 20I5).

Sejauh ini belum ada publikasi terkait penelitian tentang hubungan kadar komponen besi terhadap kualitas PRC di Indonesia. Untuk itulah penulis ingin melakukan penelitian untuk melihat seberapa besar hubungan kadar komponen besi pendonor terhadap kualitas PRC yang dihasilkan oleh UDD PMI Provinsi Sumatera Selatan.

\section{METODOLOGI}


Penelitian ini merupakan studi observasional analitik dengan desain pengambilan data potong lintang. Penelitian dilakukan di UDD PMI Sumatera Selatan dan pemeriksaan kadar komponen besi dilakukan di Balai Besar Laboratorium Kesehatan (BBLK) Palembang. Sampel penelitian merupakan plasma pendonor untuk pemeriksaan kadar komponen besi dan selang komponen PRC sebanyak 86 sampel untuk pemeriksaan kualitas PRC yang telah ditentukan dengan cara non-probability consecutive sampling. Dengan kriteria inklusi yaitu Plasma pendonor dan Komponen darah PRC telah melalui pemeriksaan Infeksi Menular Lewat Transfusi Darah (IMLTD) dan dinyatakan non reaktif, memiliki volume yang cukup dan masa penyimpanan < 24 jam. Kriteria eksklusi pada sampel yaitu jika terjadi hemolisis dengan pengamatan secara visual yang dicirikan dengan terjadi perubahan warna kemerahan pada plasma darah dalam kantong darah.

Pemeriksaan feritin menggunakan alat Vidas dengan metode ELFA, komponen besi lainnya (Serum Iron, TIBC) menggunakan alat Biosystem A 15 dengan metode ferozzine, untuk pemeriksaan kualitas eritrosit yakni pemeriksaan kadar $\mathrm{Hb}$ dan kadar Ht menggunakan alat Sysmex seri XN-I000, sedangkan pemeriksaan morfologi eritrosit dilakukan secara mikroskopis dengan menggunakan pewarnaa Wright, pembacaan sediaan dilakukan oleh satu orang dengan latar belakang pendidikan spesialis patologi klinik.

\section{HASIL DAN PEMBAHASAN}

Penelitian ini mengambarkan hasil analisis dari data yang diambil pada responden pendonor. Karakteristik responden pada penelitian ini berdasarkan jenis kelamin, usia dan frekuensi donasi.

Tabel I. Distribusi Frekuensi Berdasarkan

\begin{tabular}{|c|c|c|c|c|}
\hline & \multicolumn{3}{|c|}{ Demografi Sampel } & \multirow[b]{2}{*}{ Min-max } \\
\hline & $\mathrm{N}$ & $\%$ & Mean & \\
\hline \multicolumn{5}{|l|}{$\begin{array}{l}\text { Sosio } \\
\text { Demografi } \\
\text { Jenis Kelamin }\end{array}$} \\
\hline Laki-Laki & 57 & 66,3 & & \\
\hline Perempuan & 29 & 33,7 & & \\
\hline Usia (Tahun) & & & 35,8 & $21-52$ \\
\hline \multicolumn{5}{|c|}{$\begin{array}{l}\text { Frekuensi Donasi } \\
\text { ke: }\end{array}$} \\
\hline I Kali & 54 & 62,8 & & \\
\hline >IKali & 32 & 37,2 & & \\
\hline
\end{tabular}

Pendonor yang menjadi sampel pada penelitian ini, didominasi oleh pendonor yang berjenis kelamin laki-laki (Tabel I). Hal ini sesuai dengan data karakteristik pendonor di Indonesia tahun 2013, dimana jumlah pendonor laki-laki lebih banyak dibanding jumlah pendonor perempuan (Pusat Informasi Data, 2013). Selain itu, ada beberapa sebab yang menyebabkan pendonor laki-laki lebih banyak dari pada pendonor perempuan, hal ini berkaitan dengan biasanya lakilaki memiliki lebih banyak zat besi dari pada perempuan karena secara alamiah perempuan memiliki mekanisme menstruasi setiap bulannya sehingga memungkinkan terjadinya penurunan zat besi di dalam darah

Usia yang diperbolehkan untuk melakukan donor darah yaitu 17-60 tahun. Karena pada usia ini, perkembangan tubuh telah sempurna sehingga proses mendonorkan darah tidak akan mengganggu sistem kerja tubuh. Pada penelitian ini rerata usia sampel yakni 35,8 7,74 tahun (Tabel I). Hal ini sesuai dengan data karakteristik pendonor di Indonesia tahun 2013, dimana kelompok usia produktif 31-40 tahun merupakan kelompok umur yang paling banyak menyumbangkan darah. (Pusat informasi data, 2013).

Rentang usia 3I-40 tahun merupakan rentang usia produktif pada kehidupan manusia. Oleh karena itu baik secara fisiologi maupun proses perkembangan tubuh telah sempurna dimana fungsi tubuh masih berjalan secara optimal.

Secara keseluruhan, pada penelitian ini sebagian besar sampel dengan frekuensi donor pertama kali lebih banyak dari pada frekuensi donor lebih dari satu kali yakni sebesar $62,8 \%$. Pada beberapa penelitian menyatakan bahwa frekuensi donasi menyebabkan menurunya kadar feritin pendonor. Penelitian yang dilakukan oleh Saleh M. Abdullah menyatakan bahwa kadar feritin mengalami penurunan secara signifikan terhadap frekuensi donasi pendonor setelah melakukan transfusi lebih dari 5 kali (Abdullah, 20II). Hal ini juga dikemukakan oleh Hanifah dkk, bahwa di UDD PMI kota Yogyakarta, pendonor yang mendonorkan darahnya sebanyak 4 kali menunjukkan hubungan yang bermakna terhadap penurunan kadar feritin dan saturasi transferin (Hanifah dkk, 2016).

Tabel II. Distribusi kadar komponen besi

\begin{tabular}{lcc}
\hline Kadar Komponen Besi & N & $\%$ \\
\hline Normal & 71 & 82,6 \\
Defisiensi Tahap I & 9 & 10,4 \\
Defisiensi Tahap 2 & 6 & 7,0
\end{tabular}


Total 86 100

Seluruh sampel yang terlibat dalam penelitian ini merupakan pendonor yang telah dinyatakan layak untuk mendonasikan darahnya oleh UDD PMI Sumatera Selatan melalui serangkaian pemeriksaan baik fisik maupun laboratorium. Didapatkan data bahwa dari 86 sampel pendonor terdapat 9 (10,4\%) sampel yang mengalami defisiensi besi tahap I dan sebanyak 6 (7\%) sampel yang mengalami defisiensi besi tahap ke 2 (tabel 2). Beberapa penelitian menyimpulkan tentang status besi pendonor diantaranya penelitian Vijayram dkk di India tahun 2019 bahwa bisa terjadi defisiensi besi tahap I dan 2 pada pendonor dikarenakan pada tahapan pertama defisiensi besi tidak diikuti penurunan kadar $\mathrm{Hb}$ yang menjadi tolak ukur pemeriksaan awal bagi pendonor. Sebaliknya penelitian berbeda oleh Kartika dkk tahun 2015, menyimpulkan bahwa tidak ada perbedaan bermakna profil zat besi pendonor yang ditunjukkan dengan seluruh sampel memiliki kadar feritin normal (Kartika dkk, 20I5).

Tabel III. Distribusi Kualitas PRC

\begin{tabular}{ccc}
\hline Kualitas PRC & $\mathrm{N}$ & $\%$ \\
\hline Baik & 80 & 93 \\
Tidak Baik & 6 & 7 \\
\hline Total & 86 & 100 \\
\hline
\end{tabular}

Hasil penelitian diketahui bahwa sebanyak 6 (7\%) sampel dengan kategori kualitas PRC tidak baik (tabel 3). Penelitian ini menggunakan sampel Whole Blood (WB) yang diproses menjadi PRC dalam waktu < 12 jam dikarenakan untuk menghindari bias yang mungkin terjadi. Jenis kelainan morfologi eritrosit yang ditemukan pada penelitian ini meliputi mikrosit, ovalosit, burr cell dan sferosit yang jumlah persentasinya $>10 \%$ (Palmer et al, 20l4). Deviasi bentuk eritrosit merupakan perubahan kimia atau fisik dari membran sel ataupun sitoplasma. Keadaan mikrosit terjadi karena kekurangan zat besi sehingga sintesis eritrosit terus berlangsung dan menghsilkan ukuran sel yang lebih kecil. Burr cell merupakan eritrosit yang menunjukkan tonjolan-tonjolan pendek pada membran sel. Sel ini sering memanjang dan tidak teratur, secara klinis sel burr meningkat pada berbagai jenis anemia, perdarahan ulkus lambung dan karsinoma lambung. Burr cell terjadi akibat mekanisme fragmentasi yakni hilangnya sebagian membran eritrosit dikarenakan hilangnya Hb. Sferosit merupakan eritrosit dengan permukaan yang rata dan tanpa pucat ditengahnya, ukuran yang lebih kecil dan bundar, sel ini memiliki fleksibilitas yang rendah sehingga membuatnya mudah terhemolis. Ovalosit merupakan eritrosit yang berbentuk oval, kadang berbentuk gepeng. Perubahan bentuk yang terjadi pada eritrosit ini menyebabkan limfa memecah sel-sel tersebut secara lebih cepat. Jika pada umumnya eritrosit normal memiliki masa hidup mencapai 120 hari namun untuk perubahan bentuk eritrosit lainya hanya memliki masa hidup 10-30 hari saja.

Tabel IV. Hasil Uji Spearman dan Pearson Kadar Komponen Besi Terhadap kadar Hb, Ht dan Morfologi Eritrosit Komponen PRC

\begin{tabular}{lccc}
\hline Parameter & \multicolumn{3}{c}{ Kualitas PRC } \\
& \multicolumn{3}{c}{ (Kadar Hb, Ht dan morfologi } \\
& $\mathrm{Hb}$ & $\mathrm{Ht}$ & Morfologi \\
& $(\mathrm{r})(\mathrm{P})$ & $(\mathrm{r})(\mathrm{P})$ & $\begin{array}{c}\text { Eritrosit } \\
(\mathrm{r})(\mathrm{P})\end{array}$ \\
& & & $(-0,428)$ \\
& $(0,285)$ & $(0,157)$ & $(0,000)$ \\
Feritin & $(0,008)$ & $(0,150)$ & $(-0,44 \mathrm{I})$ \\
& $(0,295)$ & $(0,245)$ & $(0,000)$ \\
SI & $(0,006)$ & $(0,023)$ & $(0,294)$ \\
& $(-0,106)$ & $(0,180)$ & $(0,006)$ \\
TIBC & $(0,330)^{\mathrm{a}}$ & $(0,097)$ & $(-0,439)$ \\
Saturasi & $(0,244)$ & $(0,187)$ & $(0,000)$ \\
Transferin & $(0,024)$ & $(0,085)$ & \\
\hline
\end{tabular}

Berdasarkan tabel 4 diatas, dengan menggunakan uji Spearman diketahui parameter feritin, Serum Iron dan Saturasi Transferin menunjukkan adanya korelasi terhadap kadar Hb PRC, hal ini dapat diketahui dengan melihat nilai $p<0,05$. Nilai korelasi Spearman sebesar 0,285 untuk feritin dan 0,295 untuk Serum Iron sedangkan 0,244 pada Saturasi Transferin menunjukkan bahwa arah korelasi positif dengan kekuatan korelasi yang lemah.

Dengan menggunakan uji Spearman diketahui parameter Serum Iron menunjukkan korelasi terhadap kadar Ht komponen PRC yaitu dengan nilai $p=0,023$. Nilai korelasi Spearman sebesar 0,245 menunjukkan bahwa arah korelasi positif dengan kekuatan korelasi yang lemah. 
Dengan menggunakan uji Spearman diketahui parameter feritin, serum Iron, TIBC dan Saturasi Transferin menunjukkan korelasi terhadap morfologi eritrosit, hal ini diketahui dengan melihat nilai $p<0,05$. Nilai Spearman sebesar $-0,428$ untuk feritin, -0,44I untuk parameter SI dan $-0,439$ untuk Saturasi Transferin menunjukkan bahwa arah korelasi negatif dan kekuatan korelasi lemah, sedangkan untuk parameter TIBC dengan nilai Spearman sebesar 0,294 menunjukkan arah korelasi positif dengan kekuatan korelasi lemah

Sebagian besar sampel menunjukkan hasil kualitas PRC baik pada keadaan kadar komponen besi yang normal. Hal ini serupa pada keadaan kadar komponen besi dengan defisiensi besi tahap I seluruh sampel termasuk dalam kualitas PRC baik dengan defisiensi besi tahap 2 menunjukkan kualitas PRC seluruhnya dalam kategori tidak baik (tabel 4). Pada pemeriksaan awal yang dilakukan oleh peneliti terhadap parameter hematologi didapatkan bahwa sebanyak 6 sampel pendonor memiliki kadar $\mathrm{Hb}$ yang tidak sesuai dengan ketetapan AABB dan UDD PMI Pusat yakni kadar Hb kurang dari $12,5 \mathrm{~g} / \mathrm{dL}$. Kesemua sampel mengalami defisiensi besi tahap 2. Hal ini juga berpengaruh pada saat peneliti melakukan pemeriksaan $\mathrm{Hb}$ komponen PRC didapatkan nilai < 45 g. Hal ini menunjukkan bahwa $\mathrm{Hb}$ pendonor pada saat awal merupakan bagian yang berpengaruh penting terhadap kadar Hb komponen PRC yang dihasilkan. Saragih dkk dalam penelitianya menyimpulkan bahwa tidak ada hubungan kemaknaan secara statistik antara kadar $\mathrm{Hb}$ dan $\mathrm{Ht}$ komponen PRC terhadap lamanya penyimpanan, PRC yang disimpan selama 7 hari masih layak dipergunakan walaupun terjadi penurunan kadar glukosa namun masih dalam batas normal. Metode pemeriksaan $\mathrm{Hb}$ yang dilakukan di PMI Provinsi Sumatera Selatan yaitu dengan menggunakan reagen cupri sulfat dengan cara meneteskan darah pendonor ke larutan CuSO4, interpretasi dilakukan jika darah tenggelam berarti kisaran $\mathrm{Hb}>12 \mathrm{~g} / \mathrm{dL}$, jika mengapung berarti kisaran kadar $\mathrm{Hb}<12 \mathrm{~g} / \mathrm{dL}$.

\section{KESIMPULAN}

Berdasarkan hasil penelitian yang telah dilakukan, dapat disimpulkan bahwa terdapat hubungan yang signifikan kadar komponen besi pendonor terhadap kualitas PRC dengan nilai $p<0,05$.

Disarankan perlu dilakukan penelitian selanjutnya secara kohort dengan membandingkan kadar komponen besi pendonor terhadap kualitas PRC yang dihasilkan dengan pengaruh peningkatan kadar $\mathrm{Hb}$ resipien.

\section{Ucapan Terima Kasih}

Kami mengucapkan terima kasih kepada seluruh civitas Akademika Program Studi Magister Ilmu BiomedikFakultas Kedokteran Universitas Sriwijaya atas segala bantuan dan dukunganya. Kepada kepala UDD PMI Provinsi Sumatera Selatan, kami berharap dapat memberikan informasi yang berguna di kemudian hari.

\section{REFERENSI}

I. World Health Organization (WHO), 20I I.Serum Ferritin Concentrations for the Assessment of Iron Status and Iron Deficiency in Population.Micronutrient Indicators. VMNIS: I-5

2. Lynch S, 2007. Indicator of iron status of populations :red blood cell parameters: 22-27.

3. Daru J, Ktherin C, Simon J, Barbara D, Erica M, Sant R, 2017. Serum Ferritin as an Indicator of Iron Status: What Do We Need to Know?. Am j clin nutr ; 106.

4. Raveendran AV, Shiji PV, Rajini P, Suliman AQ, 2019. Iron Deficiency Anemia : an update. BMH Med.j; 6 (4) : $116-130$

5. Brittenham G, M, 20II. Iron Deficiency in Whole Blood Donors. transfusion; 5 I (3): 458-46I.

6. Peraturan Mentri Kesehatan RI (PMK) nomor 9I Tahun 2015. Standar Pelayanan Transfusi Darah. Jakarta.

7. Pusat Pendidikan Sumber Daya Manusia (PPSDM), 2018. Komponen Darah dalam Imunohematologi dan Bank Darah. Jakarta: 4-|3I.

8. Pusat Data dan Informasi, 20/3. Situasi donor darah di Indonesia. Kemenkes RI

9. Setiawan M, Caroline T, 2009. Peran Molekul HLA Dalam Proses Transplantasi Sel Punca. JKM. Vol.9 No. I Juli 2009 : 76-84.

10. Abdullah M, 20II. The Effect of Repeated Blood Donation on Iron Status of Male Saudi Blood Donors. Blood transfuse; 9: |67-7|. 
II. Hanifah D, Tri R, Budi M, 2016. Hubungan Frekuensi Donasi Darah dengan Status Besi pada Donor di Unit Donor darah PMI Kota Yogyakarta. Universitas Gajah Mada.

12. Kartika I, Lince W, Syahraswati, Rachmawati M, Darwati M, Mansyur A, 20I5. Zat Besi di Pendonor Teratur dan Yang Tidak Teratur. Indonesian Journal of Clinical Patology and Medical Laboratory, Vol. 21 , No 3 Juli 2015 : 257-260.

13. Palmer L, Brigg C, McFadden, Zini G, Burthem J, Rozenberg G, et al, 20I4. ICSH recommendations for the Standardization of nomenclature and Grading of peripheral blood cell morphological features. Int. jnl.lab.hem 37: 287303.

14. American Association of Blood Banks (AABB), 2005. Collection, Preparation, Storage, and Distribution of Components from Whole Blood Donation, InTechnical Manual 15 th edition. United State: 175-79, 185-96.

15. Bain J, Barbara, Imelda Bates, Mike, A, S, Mitchell, 2012. Practical Haematology, IIth edition. United Kingdom: Churchill livingstone; 9: I75-I8I.

16. Irfannuddin, 2019. Cara Sistematis Berlatih Meneliti. Edisi Pertama. Rayana Komunikasindo. Jakarta.

17. Marshall W, Stephen K, Marta L, 20I2. Clinical Chemistry : Disorders of Haemoproteins, Porphyrin and Iron. $7^{\text {th }}$ edition. United Kingdom: Elsevier; 289-296.

18. Saragih P, Ida A, Zulfikar L, Herman H, 2019. Pengaruh Waktu Simpan Packed Red Cells (PRC) Terhadap Kadar Hemoglobin, Hematokrit, dan Glukosa Plasma di RSUP H. Adam Malik. Intisari Sains Medis; 10 (2):50 I-505. http://isainsmedis.id/.

19. World Health Organization (WHO), 20I5.The Global Prevalence of Anemia in 20II.Geneva;WHO:I3.https://www.who.int/nutrition/publications/ prevalence_anaemia_20II/en/. 